УДК 614.8

P. І. Коваленко ${ }^{1}$, к.т.н., дои. каф. (ORCID 0000-0003-2083-7601)

А. Я. Калиновський ${ }^{\prime}$, к.т.н., доцент, нач. каф. (ORCID 0000-0002-1021-5799)

M. М. Журавський, к.т.н., дочент, заст. нач. иентру - нач. відділу (ORCID 0000-0001-8356-8600)

B. О. Кащавцева ${ }^{2}$, провідний фахівецьь (ORCID 0000-0002-1584-4754)

${ }^{1}$ Національний університет цивільного захисту Украйни, Харків, Украӥна

${ }^{2}$ Кегичівський РС ГУ ДСНС Украйни у Харківській області, Харків, Украӥна

\title{
ДОСЛІДЖЕННЯ ПРИЧИН ВИНИКНЕННЯ НАДЗВИЧАЙНИХ СИТУАЦІЙ НА ОСНОВІ ДАНИХ ОФНЦЙНОЇ СТАТИСТИКИ
}

Досліджується залежність між офіційними показниками демографічної, соціальної і економічної статистики та кількістю надзвичайних ситуацій, які виникають на території регіонів України. У якості показників демографічної, соціальної і економічної статистики були відібрані наступні: чисельність наявного населення; утворення та поводження з відходами; загальна площа житлового фонду; посівна площа зернових та зернобобових сільськогосподарських культур; реальний наявний дохід, у відсотках до відповідного періоду попереднього року. Залежність між вказаними показниками перевірялася шляхом проведення кореляційного аналізу. У 56 \% відсотках досліджуваних випадків між загальною кількістю надзвичайних ситуацій і показником чисельності наявного населення, яке проживає на території областей та в місті Києві спостерігається середня та висока сила кореляційного зв'язку. Між іншими проаналізованими в роботі показниками демографічної, соціальної і економічної статистики та загальною кількістю надзвичайних ситуацій випадків виявлення середньої та високої сили кореляційного зв'язку було значно менше. Не зрозумілою є причина отримання у 48 \% випадків від'ємних значень коефіцієнтів кореляції між загальною кількістю надзвичайних ситуацій та показником утворення і поводження 3 відходами. При цьому, числове значення коефіцієнтів кореляції дозволяє стверджувати про середню та високу силу кореляційних зв'язків. Ймовірно це може бути випадковістю і пов'язано з невеликим об’ємом вибірки. Встановлену залежність між показниками загальної кількості надзвичайних ситуацій та чисельності наявного населення було описано рівнянням лінійної регресії. Адекватність регресійної моделі перевірялася за критерієм Фішера і забезпечує коефіцієнт кореляції не нижче 0,7 , що підтверджує достовірність розробленої математичної моделі.

Ключові слова: надзвичайна ситуація, пожежа, статистичні дані, кореляційний зв'язок, прогнозна модель

\section{1. Ветуп}

Одним із завдань держави у галузі цивільного захисту є запобігання виникненню надзвичайних ситуацій (НС). Вказане завдання реалізуються шляхом постійного моніторингу оперативної обстановки та проведенням планових і позапланових профілактичних заходів. 3 метою попередження НС важливе значення має процес дослідження причин їх виникнення. Багатьма державними структурами проводиться збір різних статистичних даних, які потім офіційно подаються у формі довідок та звітів. У цих документах статистичні дані відображаються у формі таблиць в яких наведені певні числові значення. Названі документи можуть мати або не мати результатів аналізу зібраних у них статистичних даних. Частіше всього аналіз даних у звітах відображає інформацію про збільшення або зменшення тих або інших показників порівняно із попередніми звітними періодами. Результати офіційних звітів про виникнення НС як в Україні так і в інших країнах світу переважно містять дані лише про фактичні причини виникнення цих деструктивних подій, при цьому, існує гіпотеза, що на кількість НС можуть впливати певні показники демографічної, соціальної та економічної статистики. У випадку виявлення вказаної залежності можна буде запропонувати заходи щодо підвищення ефективності процесів прогнозування та запобігання НC, що є актуальною науково-практичною проблемою. 


\section{2. Аналіз літературних даних та постановка проблеми}

Згідно [1] оцінити ймовірну кількість та місця НС, які пов’язані, наприклад, зі зсувами, що відбуваються в результаті зливових дощів можна з використанням геоінформаційних систем. Для цього в роботі пропонується проводити зонування ділянок місцевості з урахуванням даних про види грунтів та кути нахилу схилів. Для забезпечення достовірності прогнозу з використанням цього способу необхідно попередньо детально дослідити ці параметри, що може бути ускладнено через особливості рельєфу місцевості.

В роботі [2] пропонується проводити прогнозування НС, які пов'язані з сезонними пожежами на основі статистичних методів аналізу часових рядів. Певну територію місцевості пропонується розділяти на окремі зони і для кожної 3 них визначати середній показник кількості пожеж за минулий період часу з урахуванням відповідного кліматичного сезону. Практичне застосування цього підходу до прогнозування на практиці не завжди дозволяє отримати точні прогнозні дані, бо значення кількості пожеж по рокам може значно відрізнятися.

В роботі [3] прогнозування $\mathrm{HC}$, які пов'язані з лісовими пожежами в окремих районах пропонується виконувати з урахуванням різних чинників, а саме: висоти над рівнем моря, рівня нахилу земної поверхні, середньорічного клімату, повноводності річок, рослинного покрову, відстані від доріг та житлових районів. Врахування багатьох чинників під час прогнозування кількості лісових пожеж не завжди дозволяє отримати у підсумку достовірні дані, тому в роботі [4] для підвищення рівня точності прогнозу пропонується враховувати лише відносну вологість та сумарну кількість опадів за певний часовий період. Згідно [5] найбільший вплив на прогнозовану кількість НС, які пов'язані з лісовими пожежами мають місяць року та температура навколишнього середовища. В цій роботі було побудовано ймовірнісну орієнтовну ациклічну прогнозну графову модель, яка враховує вказані раніше чинники. Враховуючи те, що зі зміною клімату значення середньорічних температур стали суттєво відрізнятися, тому використання цього підходу також не може гарантувати точних даних прогнозу кількості НС, які пов’язані з пожежами на наступний період.

Іншим методом, який може бути використаний для прогнозу кількості НС, які пов'язані з пожежами є метод нейронних мереж. В роботі [6] пропонується алгоритм навчання нейронної мережі, яка дозволяє виконувати прогноз кількості пожеж, які виникають на території міських населених пунктів. Аналогічний підхід пропонується також застосовувати в процесі прогнозування НС, які пов'язані iз землетрусами [7]. Поряд з цим метод прогнозування певних процесів або явищ 3 використанням нейронних мереж не можна вважати точним. Цей метод прогнозування переважно застосовується у випадках, коли спостерігається певна циклічність у виникнення подій, що не завжди може бути застосовано під час прогнозування кількості пожеж або землетрусів, а тому перед застосуванням потребує проведення попередніх досліджень.

В роботі [8] говориться про важливість точного прогнозування НС, які пов'язані з паводками але жодних методів або способів прогнозування запропоновано не було.

У роботі [9] відображаються дані про пожежі, які відбувалися в світі впродовж певного періоду спостереження та причини виїздів пожежно-рятувальних 
підрозділів. Аналіз можливої залежності між їх кількістю та іншими відомими статистичними даними або прогноз їх кількості на найближчий період в цій роботі не проводився.

В статистичних даних, які відображаються у звітах щодо виникнення НС на території України [10] вказується переважно їх загальна кількість та види. Жодних відомостей про можливу залежність чисельності НС від даних інших видів статистики як і прогнозу можливої кількості цих подій в найближчий період часу в них не наводиться.

Таким чином, невирішеною частиною проблеми є дослідження можливого впливу показників демографічної, соціальної та економічної статистики на кількість НС, які виникають на території регіонів України з метою подальшого удосконалення процесів їх прогнозування та запобігання.

\section{3. Мета та завдання дослідження}

Метою дослідження є встановлення залежності між офіційними показниками демографічної, соціальної і економічної статистики та кількістю надзвичайних ситуацій, які виникають на території регіонів України.

Для досягнення поставленої мети необхідно вирішити наступні завдання:

- дослідити залежність між показниками демографічної, соціальної і економічної статистики та кількістю надзвичайних ситуацій;

- розробити прогнозну модель для визначення кількості надзвичайних ситуацій залежно від показників демографічної, соціальної і економічної статистики та перевірити іiї адекватність.

\section{4. Дослідження залежності між статистичними даними та кількістю над- звичайних ситуацій}

Відбір звітних даних щодо показників демографічної, соціальної і економічної статистики був виконаний з офіційних форм звітності Державної служби статистики України за період з 2006 по 2019 роки. 3 причини відсутності до розгляду не приймалися статистичні дані про тимчасово окуповану територію Автономної Республіки Крим та м. Севастополя, а також про частину тимчасово окупованих територій у Донецькій та Луганській областях.

3 метою збору вказаних даних були опрацьовані звіти Головних управлінь статистики у областях та в м. Києві. Крім цього, було зібрано дані про кількість $\mathrm{HC}$, які виникали на території областей та м. Києві за аналогічний період. Дані по кількості НС за період з 2006 по 2009 роки були взяті з «Урядової інформаційноаналітичної системи виникнення надзвичайних ситуацій», а за період 32010 по 2019 рік з інформаційно-аналітичної довідки [10].

Процесу відбору показників демографічної, соціальної і економічної статистики передував аналіз причин виникнення НС на території України. Серед причин виникнення НС близько 24 \% пов'язані з пожежами та вибухами, з яких майже 52 \% припадає на пожежі у будівлях або спорудах житлової призначеності, що мало відрізняється від показників світової статистики [6]. Найбільший відсоток кількості НС припадає на НС природного характеру, а саме на медико-біологічні НС. Якщо аналізувати період за 2019 рік відсоток медико-біологічних НС становить майже 39 \% від загальної кількості НС, що головним чином пов'язано зі спалахом гострої респіраторної хвороби COVID-19, спричиненої коронавірусом 
SARS-CoV-2.

У якості показників демографічної, соціальної і економічної статистики були відібрані наступні: чисельність наявного населення, тис. осіб (показник 1); утворення та поводження з відходами, тис. т (показник 2); загальна площа житлового фонду, млн. м² (показник 3); посівна площа сільськогосподарських культур, тис. га (культури зернові та зернобобові) (показник 4); реальний наявний дохід, у відсотках до відповідного періоду попереднього року (показник 5).

В табл. 1 наведено дані щодо середнього арифметичного значення $(\Delta)$ та стандартного відхилення (б) показників, які були відібрані для аналізу. У зв’язку 3 тим, що на території м. Київ полів із зерновими та зернобобовими культурами немає, значення $\Delta$ та $\sigma$ по показнику 4 в табл. 1 не наведені.

Табл. 1. Результати аналізу статистичних даних за показниками середнього арифметичного значення та стандартного відхилення

\begin{tabular}{|c|c|c|c|c|c|c|c|}
\hline \\
\hline 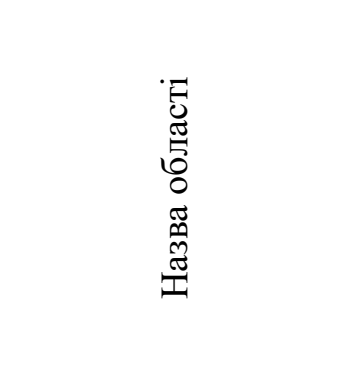 & 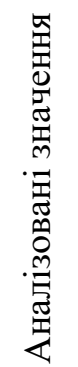 &  & 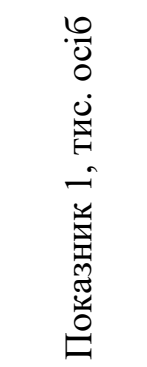 & 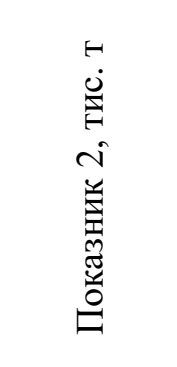 & 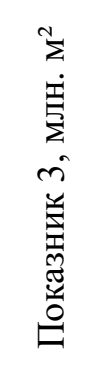 & 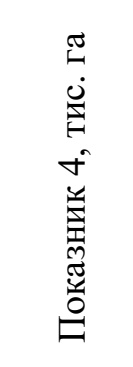 &  \\
\hline 1 & 2 & 3 & 4 & 5 & 6 & 7 & 8 \\
\hline \multirow{2}{*}{ Вінницька } & $\Delta$ & 7,9 & 1630,8 & 1680,2 & 45,5 & 845,5 & 105,6 \\
\hline & $\sigma$ & 5,4 & 41,3 & 1167,4 & 1,9 & 43,5 & 9,6 \\
\hline \multirow{2}{*}{ Волинська } & $\Delta$ & 6,4 & 1038,9 & 464,8 & 23 & 272,5 & 105,5 \\
\hline & $\sigma$ & 3,6 & 2,5 & 309,1 & 1,2 & 17 & 10,4 \\
\hline \multirow{2}{*}{ Дніпропетровська } & $\Delta$ & 10,9 & 3318,2 & 184632,2 & 78,7 & 1136,9 & 105,5 \\
\hline & $\sigma$ & 7,5 & 75 & 123509,8 & 1 & 37,7 & 10,7 \\
\hline \multirow{2}{*}{ Донецька } & $\Delta$ & 25,7 & 3318,2 & 180133,5 & 78,7 & 1136,9 & 100,6 \\
\hline & $\sigma$ & 15,7 & 75 & 127353,6 & 1 & 37,7 & 18,2 \\
\hline \multirow{2}{*}{ Житомирська } & $\Delta$ & 7,8 & 1272,3 & 424,9 & 33,5 & 397,2 & 105,6 \\
\hline & $\sigma$ & 3,3 & 32,3 & 292,3 & 0,4 & 34,9 & 10,9 \\
\hline \multirow{2}{*}{ Закарпатська } & $\Delta$ & 7,7 & 1252,1 & 137,5 & 29,4 & 86,7 & 106 \\
\hline & $\sigma$ & 2,9 & 6,7 & 140 & 1,7 & 3,3 & 10,7 \\
\hline \multirow{2}{*}{ Запорізька } & $\Delta$ & 10,2 & 1786,8 & 3953,3 & 40,9 & 884,6 & 104,7 \\
\hline & $\sigma$ & 9,8 & 46,2 & 2419,2 & 0,3 & 57,4 & 10,4 \\
\hline \multirow{2}{*}{ Івано-Франківська } & $\Delta$ & 6,1 & 1381,3 & 1367,8 & 34,2 & 143,3 & 106,2 \\
\hline & $\sigma$ & 3,9 & 3,6 & 966,9 & 2,5 & 16,2 & 10,7 \\
\hline \multirow{2}{*}{ Київська } & $\Delta$ & 10,3 & 1736,1 & 1685,6 & 57,7 & 615,9 & 106,6 \\
\hline & $\sigma$ & 7 & 16,6 & 1755,8 & 4,9 & 35,3 & 11,6 \\
\hline \multirow{2}{*}{ Кіровоградська } & $\Delta$ & 5,1 & 1001,5 & 26069,1 & 24,9 & 849,3 & 105,2 \\
\hline & $\sigma$ & 4 & 36,5 & 17338,4 & 0,3 & 37,6 & 10,3 \\
\hline \multirow{2}{*}{ Луганська } & $\Delta$ & 13,9 & 2270,7 & 5680,2 & 39,5 & 468,7 & 99 \\
\hline & $\sigma$ & 9,8 & 79,9 & 7711,3 & 18,9 & 66,1 & 19,2 \\
\hline \multirow{2}{*}{ Львівська } & $\Delta$ & 11,9 & 2536,7 & 2727,4 & 56,6 & 280,7 & 105,2 \\
\hline & $\sigma$ & 7,1 & 9,8 & 419,8 & 2,5 & 26,2 & 10,6 \\
\hline \multirow{2}{*}{ Миколаївська } & $\Delta$ & 10,9 & 1176,3 & 1870,4 & 25,8 & 890,6 & 104,6 \\
\hline & $\sigma$ & 5,3 & 26,3 & 1122,6 & 0,2 & 53,2 & 10,4 \\
\hline \multirow{2}{*}{ Одеська } & $\Delta$ & 12,5 & 2391,5 & 532,3 & 53,9 & 1201 & 105,8 \\
\hline & $\sigma$ & 5,1 & 5,8 & 392,2 & 2,1 & 30,6 & 10,8 \\
\hline
\end{tabular}


ISSN 2524-0226. Проблеми надзвичайних ситуацій. 2021. № 1(33)

\begin{tabular}{|c|c|c|c|c|c|c|c|}
\hline \hline \multicolumn{1}{|c}{1} & \multicolumn{1}{c|}{ Продовженя табл. 1. } \\
\hline \multirow{2}{*}{ Полтавська } & 2 & 3 & 4 & 5 & 6 & 7 & 8 \\
& $\Delta$ & 6,1 & 1475,1 & 13601,3 & 36,6 & 973,3 & 104,4 \\
\cline { 2 - 8 } & $\sigma$ & 3 & 47,4 & 25923 & 0,3 & 42,7 & 9,7 \\
\hline \multirow{2}{*}{ Рівненська } & $\Delta$ & 6,8 & 1156,5 & 626,8 & 25,2 & 259,5 & 105,5 \\
\cline { 2 - 8 } & $\sigma$ & 3,5 & 4 & 525,5 & 1,4 & 13,5 & 11,1 \\
\hline \multirow{2}{*}{ Сумська } & $\Delta$ & 5,3 & 1149,8 & 673,9 & 28 & 634,9 & 104,6 \\
\cline { 2 - 8 } & $\sigma$ & 1,9 & 44,6 & 402,9 & 0,3 & 53,4 & 9,9 \\
\hline \multirow{2}{*}{ Тернопільська } & $\Delta$ & 5,9 & 1079 & 786,6 & 26,2 & 469,1 & 104,8 \\
\cline { 2 - 8 } & $\sigma$ & 4,5 & 19,6 & 606 & 1,4 & 20 & 11 \\
\hline \multirow{2}{*}{ Харківська } & $\Delta$ & 12,9 & 2749,2 & 1491,3 & 65 & 976,8 & 104,3 \\
\cline { 2 - 8 } & $\sigma$ & 11,9 & 45 & 966,2 & 0,6 & 76 & 10,7 \\
\hline \multirow{2}{*}{ Херсонська } & $\Delta$ & 10,5 & 1081,2 & 311,6 & 25,4 & 719,5 & 104,5 \\
\cline { 2 - 8 } & $\sigma$ & 7,7 & 26,2 & 187,3 & 0,6 & 54,7 & 10,1 \\
\hline \multirow{2}{*}{ Хмельницька } & $\Delta$ & 5,4 & 1317,8 & 848314,8 & 34,1 & 561,9 & 104,5 \\
\cline { 2 - 8 } & $\sigma$ & 2,9 & 32,4 & 597024,8 & 1,5 & 35,1 & 9,9 \\
\hline \multirow{2}{*}{ Черкаська } & $\Delta$ & 6,9 & 1273,5 & 997 & 34,3 & 669,5 & 104,7 \\
\cline { 2 - 8 } & $\sigma$ & 5,2 & 40,8 & 708,1 & 0,3 & 20,1 & 10,1 \\
\hline \multirow{2}{*}{ Чернівецька } & $\Delta$ & 4,4 & 906,6 & 250288,5 & 21,3 & 126,9 & 105,7 \\
\cline { 2 - 8 } & $\sigma$ & 2,7 & 2,1 & 188675,4 & 1,1 & 6,7 & 11,1 \\
\hline \multirow{2}{*}{ Чернігівська } & $\Delta$ & 9,9 & 1084,2 & 498,5 & 29,8 & 668,8 & 103,7 \\
\cline { 2 - 8 } & $\sigma$ & 7,5 & 49,7 & 340,9 & 0,4 & 53,6 & 11,1 \\
\hline \multirow{2}{*}{ м. Київ } & $\Delta$ & 7,8 & 2831,1 & 1287,8 & 60,8 & - & 108,6 \\
\cline { 2 - 8 } & $\sigma$ & 4,9 & 84,3 & 1805,8 & 2,8 & - & 10 \\
\hline
\end{tabular}

У дослідженнях шляхом проведення кореляційного аналізу перевірялася залежність кількості НС, які виникали на території України в областях та в м. Києві від названих раніше показників демографічної, соціальної і економічної статистики. Значення коефіцієнтів кореляції за результатами проведеного в роботі кореляційного аналізу наведені в табл. 2.

3 метою інтерпретації отриманих числових значень коефіцієнтів кореляції була використана відома шкали оцінки сили кореляційного зв'язку Чедока. Проаналізувавши дані, які наведені в табл. 2 можна зробити висновок, що у 56 \% випадків між загальною кількістю НС та показником 1 спостерігається середня та висока сила кореляційного зв'язку. У 48 \% спостерігається середня та висока сила від'ємного кореляційного зв'язку між загальною кількістю НС та показником 2, тобто під час зростання одного показника відбувається зменшення іншого, що звичайно малоймовірно і тому викликає сумнів щодо достовірності отриманого результату. Випадків виявлення кореляційного зв'язку між показниками 3 і 4 та загальною кількістю НС значно менше порівняно з проаналізованими раніше показниками 1 і 2. Показник 5 має найменше випадків виявлених кореляційних зв'язків із загальною кількістю НС.

Табл. 2. Розраховані значення коефіціснтів кореляції

\begin{tabular}{|c|c|c|c|c|c|}
\hline 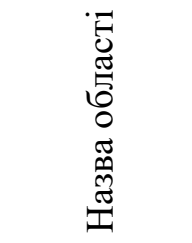 & 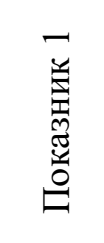 & 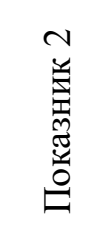 & 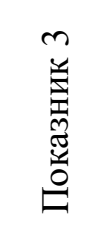 & 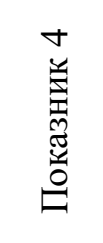 & 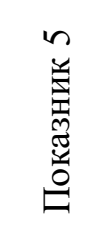 \\
\hline 1 & 2 & 3 & 4 & 5 & 6 \\
\hline Вінницька & 0,73 & $-0,74$ & $-0,64$ & $-0,56$ & 0,03 \\
\hline Волинська & $-0,05$ & $-0,22$ & 0,03 & 0,15 & $-0,18$ \\
\hline
\end{tabular}

Civi1 Security. DOI: $10.52363 / 2524-0226-2021-33-8$ 
Продовження табл. 2.

\begin{tabular}{|c|c|c|c|c|c|}
\hline Дніпропетровська & 0,72 & $-0,71$ & 0,01 & $-0,37$ & 0,3 \\
\hline Донецька & 0,82 & $-0,59$ & $-0,01$ & $-0,30$ & 0,5 \\
\hline Житомирська & 0,61 & $-0,64$ & $-0,67$ & $-0,4$ & 0,37 \\
\hline Закарпатська & $-0,14$ & $-0,45$ & $-0,53$ & $-0,59$ & 0,23 \\
\hline Запорізька & 0,72 & $-0,71$ & $-0,65$ & $-0,52$ & 0,24 \\
\hline Івано-Франківська & 0,34 & $-0,65$ & $-0,54$ & $-0,73$ & 0,45 \\
\hline Київська & 0,12 & $-0,39$ & $-0,57$ & 0,5 & 0,1 \\
\hline Кіровоградська & 0,65 & $-0,83$ & $-0,23$ & 0,41 & 0,2 \\
\hline Луганська & 0,74 & 0,12 & 0,74 & 0,64 & 0,54 \\
\hline Львівська & 0,6 & 0,18 & $-0,68$ & $-0,63$ & 0,19 \\
\hline Миколаївська & 0,7 & $-0,71$ & 0,47 & $-0,46$ & 0,1 \\
\hline Одеська & 0,09 & $-0,32$ & $-0,25$ & 0,06 & 0,2 \\
\hline Полтавська & $-0,08$ & 0,27 & $-0,16$ & 0,39 & $-0,29$ \\
\hline Рівненська & $-0,34$ & $-0,62$ & $-0,43$ & $-0,31$ & 0,23 \\
\hline Сумська & 0,15 & $-0,15$ & $-0,08$ & 0,05 & 0,11 \\
\hline Тернопільська & 0,28 & $-0,29$ & $-0,33$ & 0,37 & $-0,08$ \\
\hline Харківська & 0,53 & $-0,51$ & 0,59 & $-0,12$ & 0,07 \\
\hline Херсонська & 0,57 & $-0,42$ & $-0,36$ & $-0,4$ & 0,43 \\
\hline Хмельницька & 0,72 & $-0,14$ & $-0,64$ & $-0,08$ & 0,4 \\
\hline Черкаська & 0,67 & $-0,59$ & $-0,37$ & 0,06 & 0,38 \\
\hline Чернівецька & $-0,09$ & $-0,42$ & $-0,26$ & $-0,14$ & 0,37 \\
\hline Чернігівська & 0,7 & $-0,72$ & $-0,49$ & $-0,4$ & 0,04 \\
\hline м. Київ & 0 & $-0,23$ & 0,14 & - & $-0,14$ \\
\hline
\end{tabular}

Отже найбільша кількість кореляційних зв'язків була виявлена між загальною кількістю НС та показником чисельності наявного населення. Відповідно також виникає припущення про можливий кореляційний зв'язок між загальною кількістю НС та площею території. Цей зв'язок було перевірено. Для цього було взято дані щодо загальної кількості НС за період 2019 року та значення загальних прощ територій областей і м. Києва. За результатами кореляційного аналізу отримано коефіцієнт кореляції 0,25, що дозволяє зробити висновок про дуже низьку силу зв'язку між цими показниками.

\section{5. Розробка прогнозної моделі для визначення кількості надзвичайних ситуацій}

Встановлену раніше залежність загальної кількості НС від показника чисельності наявного населення можна описати рівнянням регресії. Перед виконанням побудови рівняння регресії спершу було перевірено силу кореляційного зв'язку між значенням середньої кількості НС по областям та м. Київ за аналізований період з 2006 по 2019 рік та значенням середньої чисельності наявного населення за аналогічний період. Значення коефіцієнту кореляції між цими параметрами становить 0,71 , що дозволяє стверджувати про високу силу зв'язку. Побудову рівняння регресії виконано на основі показників, які наведені в табл. 1. Отримане рівняння регресії має наступний вигляд:

$$
y=0,0042 x+2,14
$$

де у - прогнозоване значення кількості НС; х - чисельність наявного населення, тис. осіб.

Адекватність побудованої регресійної моделі було перевірено шляхом розрахунку F- критерію Фішера числове значення, якого становило 23,74.

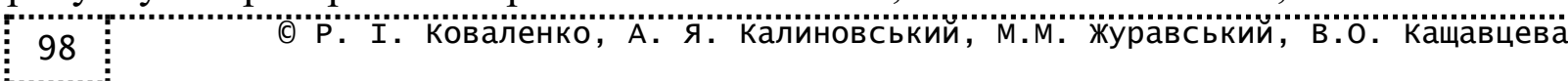


Критичне значення F- критерію Фішера для рівня значущості 0,05 та за заданих ступенів свободи $\left(v_{1}=1, v_{2}=23\right)$ становить 4,28. Оскільки розрахункове значення F- критерію Фішера більше його критичного значення, то можна дійти висновку, що регресійна модель у цілому є статистично значущою.

3 використанням запропонованої математичної моделі (1) було проведено прогноз кількості НС на період 2020 року з урахуванням показника середньої чисельності населення регіонів. Шляхом порівняння показників фактичної кількості НС, які виникали за період 2020 року і прогнозованої кількості НС за аналогічний період було встановлено, що стандартне відхилення по цим даним складає 3,34 .

\section{6. Обговорення результатів дослідження причин виникнення надзви- чайних ситуацій}

В роботі залежність між кількістю НС та різними показниками демографічної, соціальної і економічної статистики досліджувалася з використанням методів кореляційного аналізу. Саме такий відбір показників демографічної, соціальної і економічної статистики 3 масиву даних був пов'язаний 3 припущенням про їх ймовірний вплив на кількість пожеж у будівлях або спорудах житлової призначеності та пожеж, які відбуваються на відкритих територіях, наприклад, горіння сміттєзвалищ і полів із зерновими культурами.

Не зрозумілою є причина отримання у 48 \% випадків від'ємних значень коефіцієнтів кореляції між загальною кількістю НС та показником утворення і поводження з відходами. При цьому, числове значення коефіцієнтів кореляції дозволяє стверджувати про середню та високу силу кореляційних зв'язків. Ймовірно це може бути випадковістю і пов'язано з невеликим об'ємом вибірки.

Встановлення залежності між показником загальної кількості НС та показником чисельності наявного населення можна вважати очікуваним результатом. Саме чисельність наявного населення є одним із критеріїв для визначення необхідної кількості пожежно-рятувальних частин для населених пунктів і штатної чисельності сил та засобів.

Побудову прогнозної моделі для визначення кількості НС залежно від показників демографічної, соціальної і економічної статистики було виконано з використанням методів регресійного аналізу. За результатами досліджень проведених в цій роботі найбільший вплив на кількість НС, які відбуваються на певній території має показник чисельності наявного населення, що стало підставою для його вибору під час побудови регресійної моделі.

Отримана лінійна регресійна модель дозволяє визначити прогнозну кількість $\mathrm{HC}$ за рік залежно від показника чисельності наявного населення, яке проживає на відповідній території. За результатами перевірки за критерієм Фішера було підтверджено адекватність запропонованої моделі.

Під час виконання досліджень на таку тему проблемою є недостатня кількість статистичних даних, які знаходяться у відкритому доступі. Крім цього, наявні статистичні дані у звітах наводяться за достатньо невеликий період часу, що не дозволяє виконати необхідний об'єм вибірки для отримання достовірних результатів дослідження. Відповідно з метою забезпечення необхідного рівня достовірності результатів досліджень в подальшому необхідно їх проводити з більшим об'ємом вибірки статистичних даних. Вибірку даних необхідно проводити не загалом по загальній кількості НС, а по їх окремим видам і надалі досліджувати їх окремо. 


\section{7. Висновки}

1. Перевірено залежність показників демографічної, соціальної і економічної статистики із загальною кількістю надзвичайних ситуацій, які виникають на території України. У якості вказаних показників були відібрані наступні: чисельність наявного населення; утворення та поводження з відходами); загальна площа житлового фонду; посівна площа зернових та зернобобових сільськогосподарських культур; реальний наявний дохід населення, у відсотках до відповідного періоду попереднього року. Встановлено, що у 56 \% випадків між загальною кількістю надзвичайних ситуацій і показником чисельності наявного населення, яке проживає на території областей та в місті Києві спостерігається середня та висока сила кореляційного зв'язку. Між іншими проаналізованими в роботі показниками демографічної, соціальної і економічної статистики та загальною кількістю надзвичайних ситуацій випадків виявлення середньої та високої сили кореляційного зв'язку було значно менше. Перевірено гіпотезу про можливий кореляційний зв'язок між загальною кількістю надзвичайних ситуацій та площею території. Для цього було взято дані щодо загальної кількості надзвичайних ситуацій за період 2019 року та значення загальних прощ територій областей і міста Києва. За результатами кореляційного аналізу отримано коефіцієнт кореляції 0,25, що дозволяє зробити висновок про дуже низьку силу зв'язку між цими показниками.

2. Встановлену залежність між показниками загальної кількості надзвичайних ситуацій та чисельності наявного населення було описано рівнянням лінійної регресії. Для побудови цієї моделі були відібрані значення середньої кількості надзвичайних ситуацій по областям та місту Київ за аналізований в роботі період 3 2006 по 2019 рік та значення середньої чисельності наявного населення за аналогічний період. Адекватність регресійної моделі перевірялася за критерієм Фішера і забезпечує коефіцієнт кореляції не нижче 0,7 , що підтверджує достовірність розробленої математичної моделі. 3 використанням запропонованої математичної моделі було проведено прогноз кількості надзвичайних ситуацій на період 2020 року 3 урахуванням показника середньої чисельності населення регіонів. Шляхом порівняння показників фактичної кількості надзвичайних ситуацій, які виникали за період 2020 року і прогнозованої кількості надзвичайних ситуацій за аналогічний період було встановлено, що стандартне відхилення по цим даним складає 3,34.

\section{Література}

1. Alfonso G-M. A GIS-physically-based emergency methodology for predicting rainfall-induced shallow landslide zonation // Geomorphology. 2020. V. 359. 107121. doi: 10.1016/j.geomorph.2020.107121

2. Leonardo N. F., Didier A.V-O, Liang Z., Manoel F. C., Elbert E. N. M. Global fire season severity analysis and forecasting // Computers \& Geosciences. 2020. V. 134. 104339. doi: 10.1016/j.cageo.2019.104339

3. Pham B. T., Jaafari A., Avand M., Al-Ansari N., Dinh Du. T., Yen H. P. H., Phong T. V., Nguyen D. H., Le H. V., Mafi-Gholami D., Prakash I., Thi Thuy H., Tuyen T. T. Performance Evaluation of Machine Learning Methods for Forest Fire Modeling and Prediction // Symmetry. 2020. V. 12. 1022. doi: 10.3390/sym12061022

4. George E. S., Imad H. E., George M. Efficient forest fire occurrence prediction for developing countries using two weather parameters // Engineering Applications of Artificial Intelligence. 2011. V. 24. P. 888-894. doi: 10.1016/j.engappai.2011.02.017 
5. Volkan S., Omer K., Merih G. A Bayesian network model for prediction and analysis of possible forest fire causes // Forest Ecology and Management. 2020. V . 457. 117723. doi: 10.1016/j.foreco.2019.117723

6. Guangyin J., Qi W., Cunchao Z., Yanghe F., Jincai H., Xingchen H. Urban Fire Situation Forecasting: Deep sequence learning with spatio-temporal dynamics // Applied Soft Computing. 2020. V. 97. 106730. doi: 10.1016/j.asoc.2020.106730

7. Mohsen Y., Seyyed A. H., Mahdi F. Spatiotemporally explicit earthquake prediction using deep neural network / Soil Dynamics and Earthquake Engineering. 2021. V. 144. 106663. doi: 10.1016/j.soildyn.2021.106663

8. Emergency flood bulletins for Cyclones Idai and Kenneth: A critical evaluation of the use of global flood forecasts for international humanitarian preparedness and response / Rebecca E., Hannah C., Andrea F et al. // International Journal of Disaster Risk Reduction. 2020. V. 50. 101811. doi: 10.1016/j.ijdrr.2020.101811

9. World Fire Statistics. Report. № 25. URL: http://www.ctif.org/sites/default/files/2020-06/CTIF_Report25.pdf

10. Інформаційно-аналітична довідка про виникнення НС в Україні упродовж 2019 року. URL: https:/www.dsns.gov.ua/ua/Dovidka-za-kvartal/103179.html

\author{
R. Kovalenko ${ }^{I}, P h D$, Associate Professor of the Department \\ A. Kalinovskiy, , PhD, Associate Professor, Head of Department \\ M. Zhuravskij ${ }^{1}$, PhD, Associate Professor, Deputy Head of the Center-Head of Department \\ V. Kashchavtseva ${ }^{2}$, Leading specialist \\ ${ }^{I}$ National University of Civil Defence of Ukraine, Kharkiv, Ukraine \\ ${ }^{2}$ Kegychiv Regional Department of the State Emergency Service \\ of Ukraine in Kharkov region, Kharkiv, Ukraine
}

\title{
INVESTIGATION OF THE CAUSES OF EMERGENCIES BASED ON OFFICIAL STATISTICS
}

\begin{abstract}
The article examines the relationship between the official indicators of demographic, social and economic statistics and the number of emergencies that occur on the territory of the regions of Ukraine. The following were selected as indicators of demographic, social and economic statistics: population size; education and waste management; total area of the housing stock; sown area of grain and leguminous crops; real disposable income, as a percentage of the corresponding period of the previous year. The relationship between these indicators was checked by conducting a correlation analysis. In $56 \%$ of the studied cases between the total number of emergencies and the indicator of the population living in the territory of the regions, and in the city of Kiev, there is an average and high strength of the correlation. Between the other indicators of demographic, social and economic statistics analyzed in the work and the total number of emergencies, there were significantly fewer cases of detection of medium and high strength of correlations. The reason for obtaining negative values of the correlation coefficients between the total number of emergencies and the indicator of generation and waste management is not clear. At the same time, the numerical value of the correlation coefficients makes it possible to assert about the average and high strength of correlations. This is likely due to the small sample size. The established relationship between the indicators of the total number of emergencies and the population size was described by a linear regression equation. The adequacy of the regression model was checked by Fisher's criterion, and provides a correlation coefficient of at least 0,7 , which confirms the reliability of the developed mathematical model.
\end{abstract}

Keywords: emergency, fire, statistical data, correlation, predictive model

\section{References}

1. Alfonso, G-M. (2020). A GIS-physically-based emergency methodology for predicting rainfall-induced shallow landslide zonation. Geomorphology, 359, 107121. doi: 10.1016/j.geomorph.2020.107121

2. Leonardo, N. F., Didier, A.V-O, Liang, Z., Manoel, F. C., Elbert, E. N. M. 
(2020). Global fire season severity analysis and forecasting. Computers \& Geosciences, 134, 104339. doi: 10.1016/j.cageo.2019.104339

3. Pham, B. T., Jaafari, A., Avand, M., [et al.]. (2020). Performance Evaluation of Machine Learning Methods for Forest Fire Modeling and Prediction. Symmetry, 12, 1022. doi: $10.3390 /$ sym 12061022

4. George, E. S., Imad, H. E., George, M. (2011). Efficient forest fire occurrence prediction for developing countries using two weather parameters. Engineering Applications of Artificial Intelligence, 24, 888-894. doi: 10.1016/j.engappai.2011.02.017

5. Volkan, S., Omer, K., Merih, G. (2020). A Bayesian network model for prediction and analysis of possible forest fire causes. Forest Ecology and Management, 457, 117723. doi: 10.1016/j.foreco.2019.117723

6. Guangyin, J., Qi. W., Cunchao, Z., Yanghe, F., Jincai, H., Xingchen, H. (2020). Urban Fire Situation Forecasting: Deep sequence learning with spatio-temporal dynamics. Applied Soft Computing, 97, 106730. doi: 10.1016/j.asoc.2020.106730

7. Mohsen, Y., Seyyed, A. H., Mahdi, F. (2021). Spatiotemporally explicit earthquake prediction using deep neural network. Soil Dynamics and Earthquake Engineering, 144, 106663. doi: 10.1016/j.soildyn.2021.106663

8. Rebecca, E., Hannah, C., Andrea, F., [et al.]. (2020). Emergency flood bulletins for Cyclones Idai and Kenneth: A critical evaluation of the use of global flood forecasts for international humanitarian preparedness and response. International Journal of Disaster Risk Reduction, 50, 101811. doi: 10.1016/j.ijdrr.2020.101811

9. World Fire Statistics. Report № 25. Retrieved from http://www.ctif.org/sites/default/files/2020-06/CTIF_Report25.pdf [in English].

10. Informacijno-anality`chna dovidka pro vy`ny`knennya NS v Ukrayini uprodovzh 2019 roku. Retrieved from https://www.dsns.gov.ua/ua/Dovidka-zakvartal/103179.html [in Ukrainian].

Надійшла до редколегії: 13.03.2021

Прийнята до друку: 13.04.2021 